\title{
STRATEGY FOR DEVELOPMENT \\ OF AGRO-INDUSTRIAL COMPLEX AND MARKET \\ OF AGRICULTURAL LAND IN UKRAINE
}

\section{Kateryna Malinoshevska ${ }^{1}$}

DOI: https://doi.org/10.30525/978-9934-588-15-0-36

Abstract. The relevance of the topic is due to the course of formation and development of the agricultural land market in Ukraine. Land, as the economic basis of any social formation and financial-credit system, has been and remains the main resource for improving the economic situation in the country. Strategic development is a prerequisite for the efficient functioning of agriculture. The strategic direction of development of agribusiness entities is the competitiveness of goods and quality through the formation of the necessary conditions for production. To implement the effective activity of agricultural enterprises, it is necessary to create favorable conditions in the form of strengthening the industrial infrastructure, adoption of laws and regulations in the interests of agricultural enterprises, support of agricultural enterprises by state and regional authorities. Thus, of particular interest today is the problem of evaluating the performance of strategic development of agribusiness entities. The main purpose of this article is to identify methodological approaches to assessing both the quantitative and qualitative result indicators of the strategic activity of agricultural enterprises, which characterize the effectiveness of their functioning in the market. Measures are proposed to ensure the strategic development of agribusiness entities, including: improving the legislative framework at the state level; development of regional strategic development programs, as well as support for agricultural enterprises and individual projects.

\section{Introduction}

The agrarian sector of Ukraine, the basic component of which is agriculture, is system-forming in the national economy, forms the principles of preserving the sovereignty of the state - food and within certain limits

${ }^{1}$ Candidate of Economic Sciences,

Financial Director of «Highline Media» Ltd., Ukraine 
economic, environmental and energy security, ensures the development of technologically related branches of the national economy and forms the socio-economic foundations rural development.

The increased competition of regions in the modern economy and the growing impact of differences in the level of development of local territories on the stability of the regional economy necessitate the search for reserves to increase the internal potential of local territorial-administrative entities, which is based on land resources. Despite the variety of scientific research on the problem of land management, the works devoted to the formation of land markets, modeling of the optimal institutional structure of their development and regulation have received insufficient development so far.

The right choice of the best and most efficient use of land is one of the most important factors affecting the profit of the enterprise. It should be remembered that the land market as a factor of production is limited, specific and in most countries is subject to state regulation and control. One of the main features of the land market is due to the fact that the supply of land due to its absolute limitations is completely inadequate. Factors to consider when determining the most effective land use option include location potential, market demand, legal, technological and financial feasibility of an enterprise land use project.

Many factors influence the definition of a company's strategy. The interaction of these factors is specific to each industry and company and always changes over time. The main emphasis in building a land management strategy is to assess the factors of the external and internal environment. The first include the current state and trends of land market development, existing regulatory regulation, the second - the location and condition of the land plot, available management resources. The choice of land use strategy is conditioned by market opportunities to adopt the developed strategy. The possibility of implementing this strategy is considered in terms of the potential of the location of the site, legislative authorization, economic and management validity.

Despite the broad theoretical development of this problem, the study of the methodological basis for the formation of land relations and the economic mechanism of their regulation remains incomplete and requires continuation. For the development of land transformations it is necessary to deepen the research on the legal, economic, organizational and technical 
issues of this problem, the place and role of land relations in the system of social relations. They require a more thorough substantiation of the issue of land management, land cadastre and land monitoring, the mechanism of transition to paid land use, their adaptation to new economic conditions, the formation of an effective system of land use for specific conditions of Ukraine. The task is determined by the value of land, as the most important national resource and the need to formulate a basic scheme of land management of the country.

\section{Agrarian sector reform in Ukraine}

The agrarian sector has traditionally been a strong point of the Ukrainian economy, but the regulatory processes within the industry, outdated legislation and the lack of conformity of Ukrainian standards of product quality with international ones hinder the development of the industry. A significant problem for the sector remains the significant advantage of raw material exports over finished goods exports. It cuts jobs in Ukraine, increases the need for an internal market for imports. The moratorium on land sales is still in place - perhaps the most important issue to be addressed by this reform.

The reform of the agricultural sector is carried out in accordance with the Integrated Integrated Strategy and Action Plan for Agriculture and Rural Development in Ukraine for 2015-2020, developed by the Ministry of Economy together with experts from the United States Agency for International Development USAID, the World Bank, the Food and Agriculture Organization of the United Nations, European Bank for Reconstruction and Development, Organization for Economic Co-operation and Development and others (Table 1).

According to the adopted strategy, the following reform priorities have been identified:

1) creation of a stable legal system that meets international and European standards, in particular through implementation of the Association Agreement between Ukraine and the EU;

2) land reform;

3) reform of the Ministry of Agrarian Policy, state-owned enterprises, institutions and organizations belonging to the sphere of management;

4) establishment of a food security system; 
5) rationalization and elimination of existing shortcomings of the tax system;

6) development of value-added agri-food chains;

7) promoting the development of rural areas, rural territorial communities and the entire rural economy;

8) improving the competitiveness of agricultural enterprises through trade liberalization, reducing transaction costs, simplifying trade procedures and facilitating exports;

9) reforming and optimizing state research and education institutions;

10) protection of the environment and management of natural resources.

Table 1

Agrarian sector reform

\begin{tabular}{|l|l|}
\hline \multicolumn{1}{|c|}{$\begin{array}{c}\text { Disadvantages of functioning of the } \\
\text { agricultural sector }\end{array}$} & Advantages of agrarian sector reform \\
\hline Inability to sell land. & Earth will become a commodity. \\
\hline $\begin{array}{l}\text { Large state-owned agricultural enterprises } \\
\text { own thousands of hectares of land and } \\
\text { give billions in losses. }\end{array}$ & $\begin{array}{l}\text { Some state-owned enterprises will be } \\
\text { privatized. For the rest elimination or } \\
\text { appointment of effective top managers. }\end{array}$ \\
\hline The decline of rural areas. & $\begin{array}{l}\text { Expansion of the lease-development of } \\
\text { small farms. }\end{array}$ \\
\hline $\begin{array}{l}\text { Old technologies in production, overuse } \\
\text { of chemical fertilizers. }\end{array}$ & $\begin{array}{l}\text { Organic production, development of } \\
\text { niche cultures. }\end{array}$ \\
\hline $\begin{array}{l}\text { The non-transparent distribution of state } \\
\text { subsidies continues corruption. }\end{array}$ & $\begin{array}{l}\text { Objective allocation of public funds to } \\
\text { those in need. }\end{array}$ \\
\hline $\begin{array}{l}\text { More than 130 types of permits. The } \\
\text { difficulty of obtaining them has led to the } \\
\text { destruction of goods and corruption. }\end{array}$ & $\begin{array}{l}\text { There are half the number of certificates. } \\
\text { Issuance by independent laboratories. }\end{array}$ \\
\hline $\begin{array}{l}\text { The quality of Ukrainian products does } \\
\text { not meet international standards. }\end{array}$ & $\begin{array}{l}\text { Safe and quality food. Expansion of } \\
\text { markets. }\end{array}$ \\
\hline
\end{tabular}

In Ukraine, the system of agrarian statistics, while remaining at the level of the Soviet era, concentrates on gross natural indicators. No one can say for sure how much milk is produced in the country, since most come from private households, which are only augmented by agrarian statistics through extrapolation. Also, no one knows exactly how much we grow, consume and store potatoes. The reason is the same $-99 \%$ of potatoes are produced in private households (Table 2 ). 


\section{Table 2}

\section{Changing the structure of management of the agricultural sector}

\begin{tabular}{|l|l|}
\hline $\begin{array}{c}\text { of the state system of management } \\
\text { of the agricultural sector }\end{array}$ & $\begin{array}{l}\text { Decisions to improve the performance } \\
\text { of the public sector management } \\
\text { of the agricultural sector }\end{array}$ \\
\hline $\begin{array}{l}\text { Double subordination, blurring and } \\
\text { duplication of functions of state bodies. }\end{array}$ & $\begin{array}{l}\text { Liquidation of local agricultural } \\
\text { departments and creation of agro-industrial } \\
\text { management centers subordinated to the } \\
\text { Ministry of Economy on their basis. }\end{array}$ \\
\hline $\begin{array}{l}\text { There are no tools to influence agrarian } \\
\text { and political decisions. }\end{array}$ & $\begin{array}{l}\text { Reduction to 100,000 bureaucrats, } \\
\text { overcoming the corruption scheme. }\end{array}$ \\
\hline $\begin{array}{l}\text { Significant regulatory regulation of the } \\
\text { industry (various approvals, expertise, } \\
\text { procedures, etc.). }\end{array}$ & $\begin{array}{l}\text { Control over the distribution of subsidies, } \\
\text { land issues, collection of agricultural } \\
\text { statistics. }\end{array}$ \\
\hline Corruption basis. & Issues administered by the Civil Service. \\
\hline
\end{tabular}

The main problem is in making agrarian and political decisions: the authorities do not have a complete picture of the financial and economic indicators of enterprises of different forms of management. For example, the government cannot offer an adequate policy of support for the agricultural sector instead of preferential taxation, which requires the IMF to refuse, because there is no understanding of who currently needs such support: small, medium or large producers, traditional or organic farming, poultry farmers or poultry farmers. . The experience of many countries shows that agricultural policy is fraught with difficulties. The agrarian interests of farmers, landowners and suppliers of logistical resources tend to cohesion and «capture» the political process. As a result, agricultural policy tends to be wasteful and opposed to reform. Agricultural policy reform is explained by budget constraints or the need to meet international commitments. The agricultural sector development strategy is directly linked to the agro-enterprise development strategy, so it should be explored to develop it when adopting different types of strategy. When considering the market of agroindustry, which sells products has an expanded range and versatility of application. Classification of agro-enterprise development strategy based on functional types of its activity can be represented in the following form (Figure 1).

There are four main strategies in the industry:

- overall cost leadership. This type of strategy involves tight control over fixed costs, investment in productivity improvements, and minimization of maintenance, sales and advertising costs; 


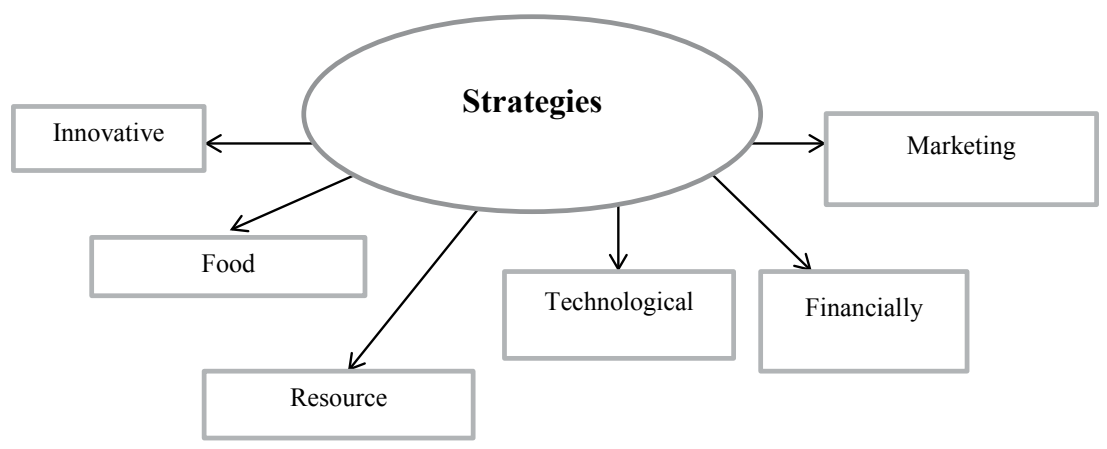

Figure 1. Classification of strategies by functional types of activity of enterprises of agro-industrial complex

- differentiation. The strategy involves giving the product distinctive qualities that are essential to the buyer.

\section{Formation of effective land management strategy}

Land reform will start in Ukraine in the near future. Landowners have formed some favorable rules for themselves in the new project: tenants will have the first right to buy the land. As a result, within a couple of years of such a law, Ukrainian agriculture, which now brings in billions of dollars in export earnings, could simply be destroyed.

Legal entities can buy Ukrainian lands. So, foreigners have access to the land. The beneficiaries of Ukrainian companies may be foreign nationals. Under current law, priority is given to persons with specialized education or engaged in agriculture. Agricultural land should be used for its intended purpose.

In Ukraine today there are about 40 million hectares of agricultural land, and a maximum of 200 thousand hectares can be owned by one person. To monitor the size of the land banks, software is required for operative data exchange between the State Register of Real Estate Rights, the State Land Cadastre, the Unified State Register of Legal and Natural Persons, and others.

It should be noted that the key mechanism for land acquisition should be a mortgage institution. 
Among the key points of the new mechanism of the land market, there are 5 following:

1) Abolition of the ban on the alienation of agricultural land of all forms of ownership;

2) Land sale at electronic land auctions;

3) The right to purchase rural land plots will be granted to citizens of Ukraine, territorial communities, the state and legal entities registered in Ukraine;

4) Mandatory registration of prices for land plots during transactions;

5) Regulation of rules for the sale of agricultural land by banks, as well as by persons to whom such land cannot be owned by ownership, for example, by foreigners.

The main tasks for the development of the agricultural land market are the following: to ensure stable employment of the able-bodied population; attraction of investments in the agro-industrial complex; capacity building of agriculture and processing industry; implementation of a small business support program. The analysis of the prospects for the development of the agricultural land market revealed the main positive aspects, namely: economic and geographical location, natural resources, recreational and tourist opportunities, economic factors. The negative aspects include: unfavorable demographic situations, low level of state support, low standard of living of the population, state of social infrastructure.

It is necessary to increase the proceeds of the land tax, which will result from: inventory of agricultural lands; allocation of land at the expense of land parcels; registration of ownership rights to unused land parcels and transfer of land plots allocated to these land parcels to new land users; attraction of new agricultural lands into the economic turnover; updating land cadastral value.

The introduction of the land sale market involves the abolition of the right of permanent use of land, which has been in force since the Soviet era; liquidation of the State Geocadastre. Changes in personnel policy must be made: to change the function of the agency, to automate its functions, to minimize the interference of the human factor, that is, corruption in land processes.

It should be noted that in Ukraine, about 14 million people live in rural areas and to varying degrees are engaged in agricultural activities. In the case of concentration of land by agroholdings, the need for so many peasants is eliminated. 1-2 million people will be needed. That is, implementation will lead to unemployment in rural areas. 
It is very important that it will be grown on Ukrainian lands. As a rule, investors will grow what is profitable and what makes a profit for the company - rapeseed, corn, sunflower. And this is a food security issue. There is a need for a clear mechanism for the sale of land, as a consequence may be that foreign investors will use the land using dangerous and harmful technologies. There are a number of regulatory techniques. Yes, the profitable method involves the analysis and forecasting of net income (derived from the exploitation of land allotment). Comparative - related to the valuation of neighboring (similar) plots. The third way is the land rest method: it consists of detailed calculations of the financial costs that need to be made to improve yields. It is a question of calculation of losses (in case of artificial replacement of soil, application of fertilizers, soil reclamation, etc.). In a real assessment of the land, it is deducted from the rent that this plot brings: it is determined taking into account the amount of money that generates annual income (in the form of bank interest). That is, the seller-landowner expects to receive at least such amount, which in the future will bring income in the form of bank interest - equivalent to the annual rent from the given land. In turn, the buyer receives not the land itself, but the income it should bring. So the price of land is the capitalized land rent or rental income for a certain number of years, which is offset by the amount of the transaction. The specific price of land as a commodity will be determined by the market situation - supply and demand, may increase or decrease depending on changes in price. The amount of demand depends on various factors: the size of the land tax, transport communications, electricity grids and inflation, since land is a real asset. Land value is also affected by declining farm incomes, location, fertility and more. The assessment of the site should be based on the results of geodetic and geological surveys (information on the composition of the soil, the level of groundwater flow, terrain). Attention should also be paid to the cadastral appraisal, which allows us to quantify the level of value of the site among the surrounding land (estimated cost).

As a result of urbanization, much of the land was removed from agricultural use and transferred to the construction of skyscrapers, roads and more. These and other factors indicate that the land market will develop and, with it, the high demand and the land valuation itself. After the moratorium is lifted, experts say the starting price for 1 hectare of agricultural land is $\$ 2,500$ on average. Statistics show that land units want to sell about $10.4 \%$ 
of owners. The offer on the land market will be 1.5-2.8 million hectares of agricultural land. The pricing principle for the sale of land can lead to the fact that a large part of the land will be in the hands of representatives of foreign structures. Such a path capitalizes on agrarian relations, but does not contribute to the formation of a real land owner and owner. It is necessary to develop a state strategy for the development of family farming in Ukraine, since the strategy of development of family farming should become the main agrarian way of life of the country.

Take the experience of selling land in France, where farmers have been working on land for 9 years, after which they are rented land. The market value of Ukrainian land today amounts to 3.5 trillion euros, which is equivalent to the GDP of Ukraine for 40 years.

Land reform will include:

1) Reducing the number of regulatory acts in agriculture;

2) Step-by-step introduction of the land market: sale of state-owned land (primarily owned by the NAAS, agrarian universities and other higher education institutions), which will set a uniform price for land;

3) Complete abolition of the moratorium on the sale of agricultural land.

\section{Restructuring of agriculture in Ukraine}

In this case, there are negative components to the land market, namely: the absence of a land market, no cost-effective and environmentally sound land use, no effective and transparent mechanism of management of state and communal land. The role of the convergence of agricultural business and science must also be determined. There is a shortage of personnel for the agricultural sector, almost no publications in the world ranking scientific publications, and almost all applied scientific developments in the agricultural sector. Agronomic science is out of place, and what used to be considered the best is imperfect, or vice versa. Technologies are changing, new varieties, new advanced equipment, new plant protection products against diseases and pests are constantly emerging, new approaches to soil treatment, soil testing, new methods of preserving and increasing soil fertility are emerging. In Ukraine, every farmer and every head of an agroholding company has to make a well-informed decision: what to buy? The supervisor seeks the advice of professionals in the agricultural sector. Ukrainian specialists often do not have the opportunity to communicate with 
an agronomist professional who is impartial and involved in international agronomic research.

Innovation and technological breakthrough is possible only if fullfledged reform of education and science in agriculture (Table 3).

Table 3

\section{Problems on directions of development of agrarian science and education}

\begin{tabular}{|l|l|}
\hline \multicolumn{1}{|c|}{$\begin{array}{c}\text { Problems of development of agrarian } \\
\text { science and education }\end{array}$} & \multicolumn{1}{|c|}{$\begin{array}{c}\text { Areas of development of agrarian } \\
\text { science and education }\end{array}$} \\
\hline $\begin{array}{l}\text { A shortage of frames for the agricultural } \\
\text { sector. }\end{array}$ & $\begin{array}{l}\text { Full independent (international) audit } \\
\text { of the National Academy of Agrarian } \\
\text { Sciences of Ukraine. }\end{array}$ \\
\hline $\begin{array}{l}\text { Lack of publications on agricultural } \\
\text { topics in the world ranking scientific } \\
\text { publications. }\end{array}$ & $\begin{array}{l}\text { Reorganization of the NAAS leaving up } \\
\text { to 10 research institutes that will show } \\
\text { the best scientific results by subordinating } \\
\text { them to the Ministry of Economy. }\end{array}$ \\
\hline $\begin{array}{l}\text { Absence of domestic applied scientific } \\
\text { developments and innovations in the } \\
\text { agricultural sector. }\end{array}$ & Education reform. \\
\hline
\end{tabular}

Changes in Europe's agriculture to preserve the environment are vigorously debated in society and are a source of outrage for farmers.

In the light of Ukraine's accession to the European Union, new problems of rural development arise, one of which is the conformity of the standards of Ukrainian agricultural products with the standards of the European Union. A thorough analysis of the consistency of national and European legislation with the system of sanitary and phytosanitary measures (SPS), carried out within the framework of the EU IFSSU project, showed that the degree of approximation to the European norms of most of the current ones in Ukraine laws, to one extent or another with regard to sanitary and phytosanitary measures (with the exception of the fishing industry) has a rating of $\langle\mathrm{B}\rangle$ «partial approximation» on a three-point scale (A, B, C). In order to raise the level of approximation of the legislation, other key laws (currently undergoing various stages of preparation) are being developed, including laws in the field of official control of feed, plant quarantine, animal by-products not intended for human consumption. In Ukraine, it is necessary to start discussing this issue today as well as the ways of rural development (Figure 2). 


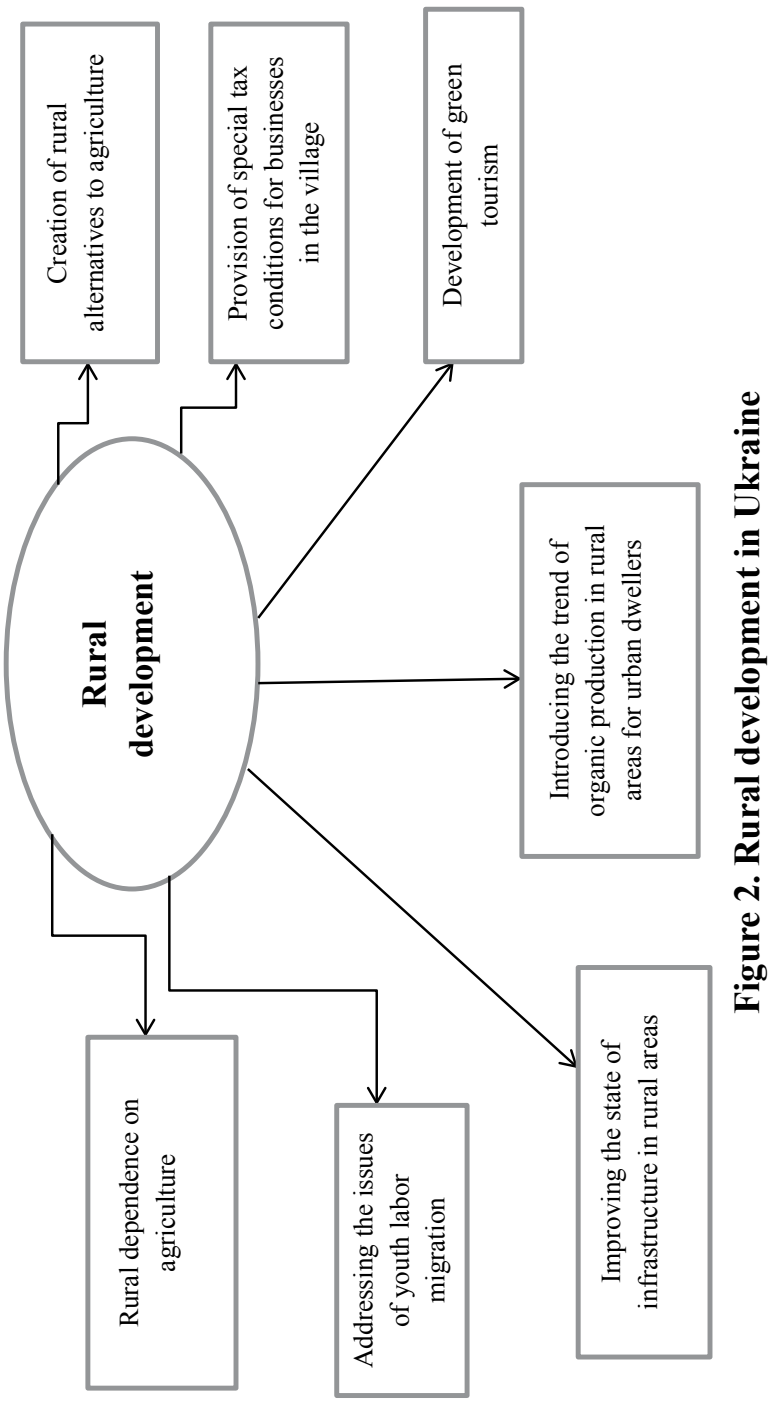


It should be noted that due to the difference in size of farms and types of products, the distribution of state payments in different farms is unbalanced. Among the factors affecting the distribution of government payments are the size of farms (area), location and types of goods produced. Today, farmers have many management options. Here are the risks they face: weather conditions, yields, pricing policies. Government policies, global markets and other factors can cause widespread changes in farm incomes. In addition, farm income is more variable than non-farm income. Risk management involves choosing from many options to reduce the financial impact of such uncertainties. In addition to participating in publicly available commodity programs for certain commodities, today farmers have private risk management options that were not available when commodity price support programs were in place. The growth of futures and option markets provides a market method for the farmer to protect himself against short-term price reductions. Other private means of stabilizing agricultural income include savings, borrowing, diversification across crops and livestock, holding agricultural production, processors at guaranteed prices, crop insurance and general income insurance, using a wide range of farming practices that reduce the cost of farming. such as irrigation, pesticide use), farm leasing, and reaping the benefits of expanding opportunities to obtain non-agricultural income. At the global level, agricultural land and other resources are most effectively used when farmers in each country face the same price signals. Prices are a market-based way of indicating what amount of produce is produced, how it is produced, where it is to be produced, in order to maximize the efficient structure of production and the best economic results for consumers.

Trade barriers, export subsidies and domestic support programs limit farmers' potential economic benefits. Agriculture will be competitive in the case of a global agricultural policy. Despite the challenges for farmers, agriculture and agriculture in general have become more efficient. Recent research has shown that global agricultural trade reform has reduced rural poverty and contributed to economic development, as the agricultural sector is important for generating income. Debt reduction and external assistance can also help reduce poverty, but trade is a much more powerful tool. In addition, development assistance does not always flow to the poor. Liberalization of agriculture is particularly important as approximately 
75 percent of the world's poor live in rural areas. The open world agricultural market has led to greater crop specialization, increased agricultural exports, and higher farm incomes in poor countries. Support for agriculture can take many forms, with some countries offering farmers fixed payments, regardless of what they produce. Disbursement data are one-off transfers of income to economic entities that depend on current or future production, use of factors or prices for goods. From an economic point of view, the best way to provide agricultural support will be to focus on forms of support that have less impact on achieving the desired policy objectives.

Land conservation work programs support the adoption and maintenance of land management practices and the structural preservation of agricultural land, including crops and pastures and, in some cases, forestland. Agricultural land conservation programs help to keep the land in agricultural use by acquiring the owner's right to make changes in use. The development of programs should facilitate the trade effect affecting production (in particular, the impact on increased production). If commodity support programs are aimed at helping low-income households, these programs today are not up to the task. Technological advances in agriculture have influenced the long-term growth of agricultural productivity in Ukraine. Innovations in animal genetics, plants, chemicals, equipment, and farm organization have allowed for continued growth in production, using far less labor and farmland. Productivity can be measured in a variety of ways, such as yield (production per unit of land is a one-factor indicator). However, a one-factor performance measure, like yield, is sensitive to changes in the use of other resources and does not necessarily reflect overall technological progress. For example, crop yields may increase as more fertilizers and pesticides are used, even if production technology is not improved. On the other hand, total factor productivity (TFP) takes into account the contribution of all resources, including capital, land, labor and intermediate resources such as agricultural chemistry and energy. Annual TFP growth is the difference between the growth of all agricultural output and all inputs.

Increasing agricultural productivity is affecting the global food market. Slowing productivity growth can lead to higher product prices. It can also put pressure on low-income households as they spend more of their income on food. Although in the short term, transitional events - such as energy shocks or supply shortages due to bad weather - can cause agricultural commodity prices to rise, 
the long-term upward trend in agricultural productivity has increased food security by reducing real (inflation-adjusted) agricultural output. Competitive use of labor and land from other industries or goals has led to increased costs of these resources. Technological advances have also made resources such as machinery and agricultural chemistry more accessible to farmers.

Investments in public and private agricultural research are major drivers of technical change, leading to long-term productivity gains. A successful agrarian sector supports economic growth. By producing a wide variety of products, farmers provide a safe and secure household food supply. Farmers invest in their businesses by supporting the mechanical engineering and other industries, buying goods and services from local businesses. The high level of production of farms, in turn, improves the prospects for further business: food companies and biofuels, oil refineries.

Farm development strategies can be as follows:

1) Export opportunities for farmers and farmers;

2) Formation of bills on the development of farms;

3) Reducing barriers to agricultural exports;

4) Promoting export opportunities for small and emerging farmers and processors;

5) Investing in transport infrastructure;

6) Ensure comprehensive immigration reform in order to ensure the stability of the agricultural workforce.

The country's government must act strategically to meet the challenges of making an important strategic choice for positioning agricultural products on the world market. The key role for the public sector is to create the conditions that ensure the development of economically competitive agro-industrial enterprises. Some of the key issues include improved infrastructure and access to finance, as well as macroeconomic and trade policies that foster investment and innovation. Based on a wide range of statistics and empirical research sources, the contribution of agro-industry to economic development is very important in our country. Politics in the global economy is about defining one's own role in fostering economic progress. The role of the state at its level requires enforcement of laws that determine property rights, enforce treaties and resolve disputes. Without state action, the agricultural market cannot exist. Investing in infrastructure that helps to provide the necessary capabilities that will allow to form an effective mechanism of markets and 
enterprises of the agro-industrial complex. The state provides services such as finance, transportation and information. Here are the conditions that are necessary to influence economic development:

1) The underlying macroeconomic climate should facilitate the efficient allocation of resources;

2) Infrastructure projects can only increase profits when there are sufficient other resources available; infrastructure investment cannot create economic potential, but only develop it;

3) The conditions of production and consumption are those that provide the desired level of reliability and quality of service for the user;

4) Infrastructure will be cost-effective and environmentally friendly if user fees are charged.

Insufficient infrastructure impedes the ability of countries and industries to participate in international trade. Increasing globalization is driven not only by economic factors such as trade, politics and the integration of financial markets, but also by the development of information technology and transport. These infrastructure investments are related to productivity and aggregate sales. Companies in the agricultural sector have difficulty accessing capital. Agribusiness is perceived as a high-risk, low-return business. As a result, the agribusiness portfolio is not an attractive option for investors, who tend to strive for high returns if high risk. The risks of agribusinesses are different from those in other sectors, which are, first of all, price and production risks. These risks have contributed to the increased globalization of free trade in agricultural commodities. The credit crunch in agribusiness is further exacerbated by the ignorance of the majority of bankers in the sector, which increases the likelihood of rejection of loan applications completely if low profitability is perceived. There is an urgent need to create an enabling environment for providing financial services to the sector.

Vision of the agro-industrial complex as a sector tied to the production systems of rural areas, dependent on seasonal factors and requiring large land resources, in the foreseeable perspective may become obsolete due to the development of urbanized technologies agriculture and industrial synthesis of food. Everyone gets it today wider development of greenhouse complexes, including those located in large cities, with highly automated production processes and placement of plants in several tiers. Small home systems accessible to the general public are being developed hydroponics 
and aeroponics, which can significantly increase food security of large cities, create additional incentives for retailers in direction of improving the quality of public services. Amid these nascent trends that over the years can radically change agricultural markets. In case of inability of domestic agribusiness to quickly adapt to what is happening implementing change strategies based on outdated ideas about agricultural production can cause losses in the long run existing positions in the global food and technology market, inability to occupy niches in fundamentally new market segments, reduced competitiveness traditional agricultural producers in the domestic market.

The technological gap between large agricultural holdings and small farms is especially acute due to the low availability of loans for small agribusiness while at the same time high risks of investing in it. The solution to this problem may be the promotion of agricultural cooperation and credit financing of large cooperatives. A balanced and careful policy regarding admission to domestic market of large multinational companies in the agricultural sector. On the one hand, their presence in the domestic market on a certain scale is useful for raising the level of competition and, accordingly, product quality. Joint projects and enterprises with them, including cooperation with research centers, can also be useful. Particular attention should be paid to the formation and promotion of domestic companies with the potential to enter global markets. As the openness of the agro-industrial complex increases, caution must be taken to protect the intellectual property of domestic centers of competencies: a high degree of localization of production of foreign companies in the field of biotechnology, agricultural chemistry, agricultural and food engineering.

\section{Conclusions}

Demand for food and agriculture is changing every year. Increasing per capita income, increasing urbanization are driving greater demand for high quality goods, processed products and finished products. The use of agricultural products, including cereals and oilseeds, as raw materials for bioenergy production is also increasing. International trade and communications are accelerating demand changes. Opportunities for diversification and added value in agriculture reflect changes in consumer demand. The prospects for further growth in demand for agricultural products are an incentive to increase attention to agricultural development in the context of economic 
growth, food security, and poverty reduction strategies. The agricultural industry is understood here as a component of the manufacturing sector, with a high multiplier effect in terms of job creation. The agro-industrial enterprise stimulates business, its direct socio-economic impact occurs in rural areas. For Ukraine, the agro-industrial complex has traditionally remained a priority and strategically important sector of the economy. That is why the full utilization of the export potential of the country's agro-industrial complex will play a key role in its integration into the world economic space. All of the above actualizes the definition of the strategy of development of agroindustrial complex of Ukraine in the conditions of intensified international competition. National food security requirements limit the ability to remove international trade barriers. The position of national governments in many countries on food security is increasingly at odds with the principles of free international trade. Within the framework of international mechanisms, the country is able to restrict access to its own food markets through the use of non-tariff regulation measures, effectively seeking significant openness in domestic markets. This state of affairs weakens the production potential of agroindustrial complex. The agro-industrial complex requires a balanced policy of regulation of domestic markets for agricultural raw materials and food, which, on the one hand, will provide some level of competition from foreign suppliers, on the other - will not lead to a loss of domestic suppliers share in the domestic market. The implementation of such a policy will, and will already lead to appropriate restrictions on the part of potential food importers. Therefore, more attention should be paid to supporting the export of agricultural products.

Thus, the formation of a single strategy for the development of the agro-industrial complex of Ukraine will give grounds to identify the key objectives of state policy in the sphere of foreign economic activity, the creation of an effective export support system, which will ensure the sustainable development and realization of the export potential of the agroindustrial complex of Ukraine.

\section{References:}

1. Ambrosov V.Y. (2013). Rynok i stratehiia rozvytku silskohospodarskykh pidpryiemstv [The market and the strategy of development of agricultural enterprises]. Ekonomika APK, vol. 10, pp. 72-79.

2. Andriichuk V.G. (2013). Novi typy ahropromyslovykh formuvan v ramkakh natsionalnoi stratehii ahrarnoho rozvytku [New types of agroindustrial formations 
within the framework of the national agrarian development strategy]. Ekonomika $A P K$, vol. 1, pp. 1-3.

3. Goncharov S.M., Kushnir N.B. (2009). Interpretatyvnyi slovnyk ekonomista [Interpretative dictionary of the economist]. Kyiv: Centre of educational literature. (in Ukrainian)

4. Arefieva O.V., Herasymchuk N.A. (2006). Upravlinnia formuvanniam pidpryiemnytstva [The management of the entrepreneurship formation]. Kyiv: Vydavnychyi dim «Korporatsiia». (in Ukrainian)

5. Vovk I.P. (2012). Osoblyvosti vprovadzhennia zakhodiv resursozberezhennia ta metodyka vyznachennia yikh efektyvnosti na mashynobudivnykh pidpryiemstvakh $\mathrm{v}$ konteksti resursonomiky [Features of resource conservation measures and methods of their effectiveness in engineering enterprises in the context of resourcenomy]. Visnyk of Sumy State University. Economics Series, no. 4, pp. $107-117$.

6. Yermoshenko M.M., Hanushchak-Yefimenko L.M. (2010). Mekhanizm rozvytku innovatsiinoho potentsialu klasteroobiednanykh pidpryiemstv [The mechanism of innovation potential development of the cluster-united enterprises]. Kyiv: National Academy of Management. (in Ukrainian)

7. Yerokhin S.A. (2002). Strukturna transformatsiia natsionalnoi ekonomiky (teoretyko-metodolohichnyi aspekt) [The structural transformation of national economy (theoretical and methodological aspect]. Kyiv: Svit Znan. (in Ukrainian)

8. Kadiievskyi V.A., Burtseva T.I. (2011). Ekonomichnyi mekhanizm realizatsii rehionalnoi polityky enerhozberezhennia ta resursoefektyvnosti $\mathrm{v}$ okremykh vydakh diialnosti [The economic mechanism of implementing the regional energysaving and energy-efficiency policy in certain types of activities]. Naukovyi visnyk Natsionalnoi akademii statystyky, obliku ta audytu, no. 3, pp. 56-61.

9. Kondratenko N.O. (2010). Startehiia resursozberezhennia rehionalnykh ekonomichnykh system [The resource-saving strategy of the regional rconomic systems]. Kharkiv: NTM. (in Ukrainian)

10. Nazarbaev N.A. (1992). Strategiia resursosberezheniia $i$ perehod $k$ rynku [The resource-saving strategy and transition to the market] Moscow: Mashinostroenie. (in Russian)

11. Liashenko I.O. (2012). Osoblyvosti ta perspektyvy rozvytku resursozberezhennia $v$ Ukraini [Specifics and perspectives of resource saving in Ukraine]. Efektyvna ekonomika, no. 11. Available at: http://www.economy.nayka.com.ua/ ?op $=1 \& z=1537$ (accesse 10 May 2019).

12. Nelep V.M. (2015). Tendentsii rozvytku silskoho hospodarstva $\mathrm{v}$ Ukraini ta sviti [World and Ukrainian trends of agricultural development]. Ekonomika APK, no. 7, pp. $100-105$.

13. Skrypnyk A.V., Herasymchuk N.A. (2013). Ekonomichni i finansovi ryzyky [The economic and financial risks]. Kyiv: TsP «KOMPRYNT». (in Ukrainian)

14. The statistical publication (2015). Zovnishnia torhivlia Ukrainy tovaramy ta posluhamy u 2010-2014 rokakh [External trade of Ukraine in 2010-2014]. Available at: http://www.ukrstat.gov.ua (accesse 10 May 2019). 